\title{
Yet another record of Scylla serrata Forsskål, 1775 (Crustacea: Decapoda: Portunidae) from the western Atlantic
}

\author{
Cassiana Baptista Metri ${ }^{1,3}$; Pablo Damian Borges Guilherme ${ }^{1,4}$ \& Marcos Tavares ${ }^{2}$ \\ 1 Universidade Estadual do Paraná, Programa de Pós-Graduação em Ciências Ambientais - Ambientes Litorâneos e Insulares. Paranaguá, PR, Brasil. \\ ${ }^{2}$ Universidade de São Paulo (USP), Museu de Zoologia (MZUSP). São Paulo, SP, Brasil. \\ ORCID: http://orcid.org/0000-0002-7186-5787. E-mail: mdst@usp.br (correspondence author) \\ 3 ORCID: http://orcid.org/0000-0001-6432-4280.E-mail: cassiana.metri@unespar.edu.br \\ ${ }^{4}$ ORCID: http://orcid.org/0000-0001-7471-6907.E-mail: pablo.borges@unespar.edu.br
}

\begin{abstract}
The Indo-Pacific edible swimming crab Scylla serrata is reported here for the fifth time from the western Atlantic including a failed attempt of introduction to Florida for aquaculture purposes in the years 1960's. The species had been recorded from Brazil in the early 1980's and in 2011 and from the Caribbean coast of Colombia in 2013. The capture of a third specimen in southeastern Brazil on 24 August 2020 is discussed here. On all occasions individuals found in Brazil were adults captured alive near port areas. The occurrence of S. serrata in disparate time periods in the western Atlantic (1983, 2011, 2013 and 2020) is regarded as an indication of low inoculation pressure.
\end{abstract}

Key-Words. Giant mud crab; Alien marine species; Shipping; Charybdis hellerii; Indo-Pacific; Brazil.

\section{INTRODUCTION}

Swimming crabs of the genus Scylla De Haan, 1833 disappeared from the Atlantic Ocean since the Miocene (Rathbun, 1935; Via, 1941; Veiga Ferreira, 1954). The genus, currently restricted to Indo-Pacific waters, consists of four species, among which Scylla serrata Forsskål, 1775 (see Keenan et al., 1998; Brockerhoff \& McLay, 2011, and references therein). Recently, however, S. serrata has been transported to new areas through man's mediation. Intentional introductions were attempted in Florida and Hawaii for aquaculture purposes. These intentional attempts failed in Florida (Park, 1969), but succeeded in Hawaii, where S. serrata became established (Carlton \& Eldredge, 2009). Scylla serrata has also been inoculated thrice into the western Atlantic likely as a result of shipping activities, namely in Brazil (Peruíbe, in 1983; Sepetiba in 2011) and Colombia (Cartagena Bay, 2013) (Melo, 1983; Tavares \& Mendonça Jr., 2011; Lemaitre et al., 2013). The capture of a third specimen found alive on the southeastern Brazilian coast, is discussed here.

\section{MATERIAL AND METHODS}

One large male of Scylla serrata (Figs. $1 \mathrm{~A} ; 2 \mathrm{~A}-\mathrm{C}$ ) was caught alive in a gill net by fishermen Ruan
Carlos do Rosário Ribeiro and Izair Cassilha Ribeiro at a depth of about 1.5-4 m at Saco do Tamarutaca, Paranaguá Bay, southeastern Brazil (approximately $25^{\circ} 26^{\prime} 24^{\prime \prime} \mathrm{S}, 48^{\circ} 26^{\prime} 23^{\prime \prime} \mathrm{W}$ ) (Fig. 1B). The specimen (carapace length and width, $\mathrm{cl} 183,03 \mathrm{~mm} \times$ cw $119,06 \mathrm{~mm}$, respectively) is deposited at the

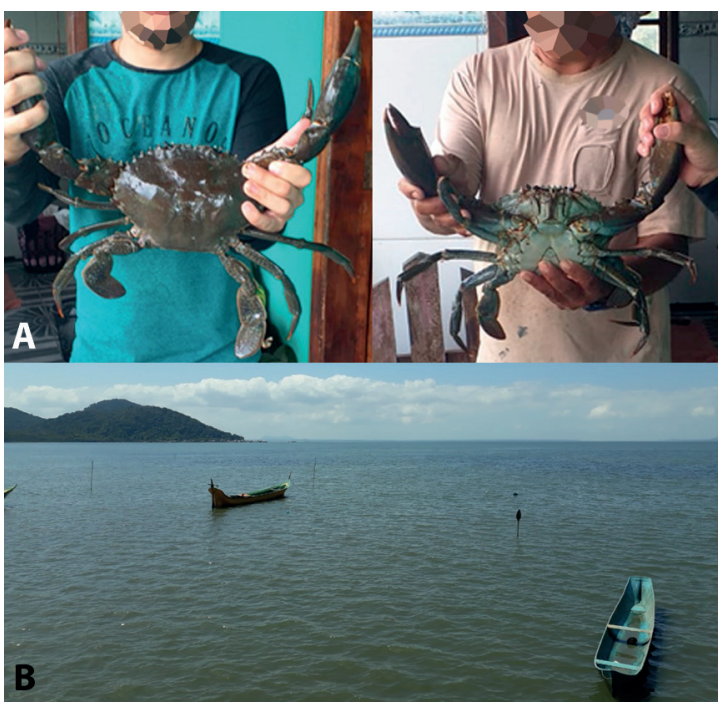

Figure 1. (A) Scylla serrata (Forsskål, 1775), carapace length and width cl 183,03 mm $\times \mathrm{cw} 119,06 \mathrm{~mm}$, respectively (MZUSP 41291). Male captured by fishermen on 24 August 2020 at Saco do Tamarutaca, Paranaguá Bay, Paraná, Brazil. (B) General aspect of Saco do Tamarutaca, Paranaguá Bay, Paraná, Brazil.
Pap. Avulsos Zool., 2020; v.60: e20206062

http://doi.org/10.11606/1807-0205/2020.60.62

http://www.revistas.usp.br/paz

http://www.scielo.br/paz

Edited by: William Ricardo Amâncio Santana

Received: 13/10/2020

Accepted: 19/10/2020

Published: $16 / 11 / 2020$
ISSN On-Line: 1807-0205

ISSN Printed: 0031-1049

ISNI: 0000-0004-0384-1825 
Museum of Zoology, University of São Paulo (MZUSP 41291). A number of fouling organisms were observed on it.

\section{Comparative material}

Scylla serrata: Brazil: 1 female, cl 148 mm, cw 238 mm (MZUSP 24232), off Sino Beach (approximately $23^{\circ} 04^{\prime} 53^{\prime \prime} \mathrm{S}$, $\left.44^{\circ} 00^{\prime} 30^{\prime \prime} \mathrm{W}\right)$, Marambaia Island, Sepetiba Bay, State of Rio de Janeiro, around 9 m. 1 female, cl 152 mm, cw 220 mm (MZUSP 5310), Peruíbe, State of São Paulo, around $15 \mathrm{~m}$. French Polynesia: 1 male, 1 female (MZUSP 37623), Huahine, stn R14, Society Islands, J. Poupin coll., don., reefs.

\section{RESULTS AND DISCUSSION}

\section{Taxonomy}

The male of Scylla serrata from Paranaguá Bay agrees well with the comparative material (listed above) and with the diagnoses, color pattern and illustrations provided by Keenan et al. (1998).

\section{Possible vectors and point of entry}

The vector of introduction of S. serrata in the Paranaguá Bay is unknown, but possibilities include shipping activities, including but not limited to live adults carried on board ship as fresh food and possibly discarded intentionally or unintentionally into the harbor (see also Tavares \& Mendonça Jr., 2011; Lemaitre et al., 2013). Indeed, the Paranaguá Bay is home to the Paranaguá Port $\left(25^{\circ} 30^{\prime} 07.0^{\prime \prime} \mathrm{S}, 48^{\circ} 30^{\prime} 43.2^{\prime \prime} \mathrm{W}\right)$, which is likely the point of entry for S. serrata. The port is the largest exporter of agricultural products from Brazil and the Bay is known to host a number of alien and cryptogenic species (Neves \& Rocha, 2008; Rocha \& Kremer, 2005; Tavares, 2011), including a well-established population of the Indo-West Pacific Charybdis hellerii (A. Milne-Edwards, 1867). A single specimen of the alien swimming crab, Liocarcinus navigator (Linnaeus, 1758) was captured alive also off the coast of Paranaguá (Tavares \& Rössener, 2019).

\section{Single and occasional records}

It has been submitted that single and occasional records of invasive species possibly represent an ear-

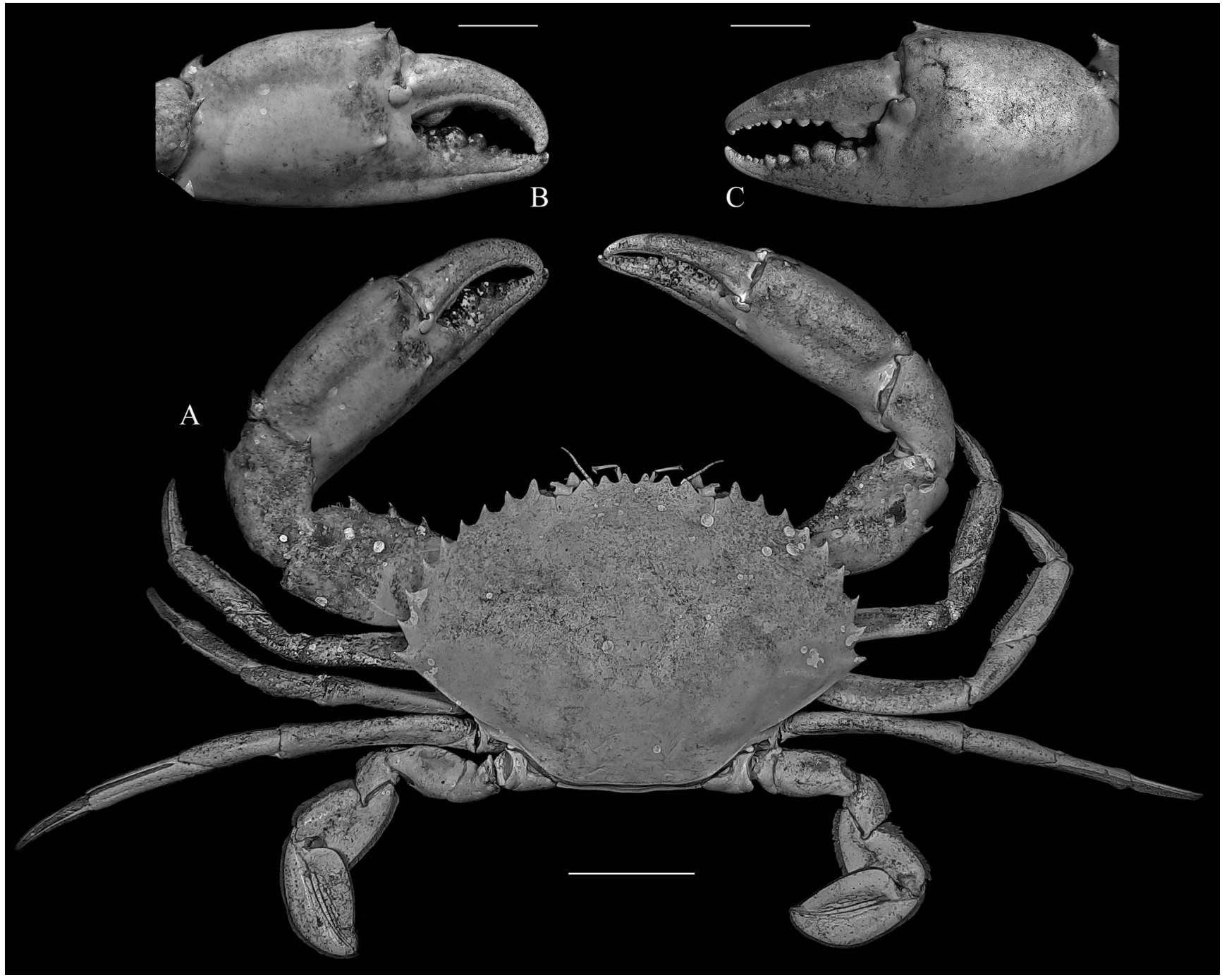

Figure 2. Male Scylla serrata (Forsskål, 1775) (MZUSP 41291). (A) Habitus, dorsal view. (B, C) Mesial and lateral views of the left cheliped. Scale bars: (A) 50 mm. (B, C) 30 mm. 
ly warning for human-mediated connectivity between donor and receiver areas, while the frequency of catches possibly represent a reflection of the level of inoculation pressure (Tavares \& Rössener, 2019). Indeed, the occasional presence of the Indo-West Pacific C. hellerii in the western Atlantic (WA) in 1965, preceded in several years the establishment of self-sustained populations of C. hellerii in the WA in the late 1980's.

The occurrence of S. serrata in disparate time periods in the western Atlantic might be an indication of low inoculation pressure. The species is not established in the western Atlantic. However, these occurrences being in localities rather close to one another in Brazil is of interest as an indication of southeastern Brazil as a potential receiver area for this species in the southwestern Atlantic.

\section{ACKNOWLEDGEMENTS}

We are grateful to Guilherme José Silvério and Romildo F. do Rosario for having called our attention to the present specimen of Scylla serrata and to fishermen Ruan Carlos do Rosário Ribeiro and Izair Cassilha Ribeiro for having made the specimen available to us. Nathalia G. dos Santos and Adriana Cristina Almiron de Rolon assisted with the photographs at the laboratory, Fig. 2. MT thanks CNPq (303122/2016-1) for supporting studies on the systematics of decapod crustaceans.

\section{REFERENCES}

Brockerhoff, A. \& McLay, C. 2011. Human-mediated spread of alien crabs. In: Galil, B.S.; Clark, P.F. \& Carlton, J.T. (Eds.). In the wrong place - alien marine crustaceans: distribution, biology and impacts. New York, Springer. p 27-106.

Carlton, J.T. \& Eldredge, L.G. 2009. Marine bioinvasions of Hawai'i. The introduced and cryptogenic marine and estuarine animals and plants of the Hawaiian Archipelago. Bishop Museum Bulletin in Cultural and Environmental Studies, 4: 1-202.

Forsskål, P. 1775. Descriptiones Animalium Avium, Amphibiorum, Piscium, Insectorum, Vermium; quae in Itinere orientali observavit. Petrus Forskål.
Post Mortem Auctoris editit Carsten Niebuhr. Adjuncta est materia Medica Kahirina. Hauniae, Heineck et Faber. DOI

Keenan, C.P.; Davie, P.J.F. \& Mann, D.L. 1998. A revision of the genus Scylla De Haan, 1833 (Crustacea: Decapoda: Brachyura: Portunidae). The Raffles Bulletin of Zoology, 46: 217-245.

Lemaitre, R.; Campos, N.H.; Viloria Maestre, E.A. \& Windsor, A.M. 2013. Discovery of an alien crab, Scylla serrata (Forsskål, 1775) (Crustacea: Decapoda: Portunidae), from the Caribbean coast of Colombia. Biolnvasions Records, 2(4): 311-315. D0I

Melo, G.A.S. 1983. A ocorrência no litoral brasileiro de um Portunidae (Crustacea: Decapoda: Brachyura), originário do Indo-Pacífico. Revista Brasileira de Zoologia, 1: 159-167.

Milne-Edwards, A. 1867. Descriptions de quelques espèces nouvelles de Crustacés Brachyoures. Annales de la Societé Entomologique de France (série 4), 7: 263-288.

Neves, C.S. \& Rocha, R.M. 2008. Introduced and cryptogenic species and their management in Paranaguá Bay, Brazil. Brazilian Archives of Biology and Technology, 51(3): 623-633. DOI

Park, J.R. 1969. A preliminary study of portunid crabs in Biscayne Bay. Quarterly Journal of the Florida Academy of Sciences, 32: 12-20.

Rathbun, M.J. 1935. Fossil Crustacea of the Atlantic and Gulf coastal plain. Special Paper of the Geological Society of America, 2: 1-160.

Rocha, R. M. \& Kremer, L.P. 2005. Introduced ascidians in Paranaguá Bay, Paraná, southern Brazil. Revista Brasileira de Zoologia, 22(4): 1170-1184. DOI

Tavares, M. 2011. Alien decapod crustaceans in the Southwestern Atlantic Ocean. In: Galil, B.S.; Clark, P.F. \& Carlton, J.T. (Eds.). In: the wrong place - alien marine crustaceans: distribution, biology and impacts. Invading Nature. Springer, New York, pp. 251-267. DOI

Tavares, M. \& Mendonça Jr., J.B. 2011. The occurrence of the Indo-Pacific swimming crab Scylla serrata (Forskål, 1775) in the Southwestern Atlantic (Crustacea: Brachyura: Portunidae). Aquatic Invasions, 6(suppl. 1): S49-S51. D0I

Tavares, M. \& Rössener, E. 2019. Occurrence of the eastern Atlantic, Mediterranean, and Black Sea swimming crab Liocarcinus depurator (Linnaeus, 1758) (Brachyura: Carcinidae) in the Western Atlantic. Journal of Crustacean Biology, 39(2): 193-195.

Veiga Ferreira, 0. 1954. Malacostráceos do Miocênico marinho de Portugal. Comunicações dos Serviços Geológicos de Portugal, 35: 57-58.

Via, L. 1941. Los cangrejos fosiles de Cataluña. Boletín del Instituto Geológico de España, 55, 55-73. 